\title{
Effect of stabilizer reagents on zeta potential of kaolinite and its relevance to electrokinetic treatment
}

\begin{abstract}
The influence of the dispersion of $\mathrm{pH}$ and concentration of chemicals on zeta potential of kaolinite were investigated. Adding the cationic species led to an increase of the zeta potential, contrary to measuring done in water. The results proved that even a very low concentration of the cationic species $(0.001 \mathrm{~mol} / \mathrm{L})$ causes a remarkable change of the zeta potential. The zeta potential of the kaolinite soils varied from 204.6 to- $41.9 \mathrm{mV}$, according to the chemical reagents and electrolyte concentration. Moreover, the negative charge in kaolinite soils is highly $\mathrm{pH}$ dependent and surface charge of pure kaolinite is dropped to zero, $(\mathrm{pH} \mathrm{pzc})$ at $\mathrm{pH}$ 3.2-3.5. The greater electrolyte concentration resulted in the thicker diffuse double layer and higher $\mathrm{pH}$ at the iso-electric point. While, for some reagents there was no isoelectric point that to be observed, $\mathrm{Al} 2 \mathrm{SO} 34$ increase the $\mathrm{pH}$ at isoelectric point and $\mathrm{Na}$ $2 \mathrm{CO} 3$ as well as $\mathrm{CH} 3 \mathrm{COONa}$ led to decrease in $\mathrm{pH}$ at iso electric point of suspension kaolinite. Results revealed that presence of low molecular weight $\mathrm{CaCl} 2, \mathrm{Al} 2 \mathrm{SO} 34, \mathrm{H} 3 \mathrm{PO}$ 4, $\mathrm{Na} 2 \mathrm{Sio} 2, \mathrm{CH} 3 \mathrm{COONa}$, and $\mathrm{Na} 2 \mathrm{CO} 3$ led to a increase in diffuse double layer thickness in order of $\mathrm{CaCl} 2, \mathrm{Al} 2 \mathrm{SO} 34, \mathrm{Na} 2 \mathrm{CO} 3$ and $\mathrm{H} 3 \mathrm{PO} 4$, and $\mathrm{Na} 2 \mathrm{SiO} 4$, and electrolyte concentration has important effect on such incrasing. Based on results of 6 and $\mathrm{pH}$ observed from using different cationic species, those $\mathrm{pH}$ pzc which are more close to the soil $\mathrm{pH}$ ( 6 is dropped to zero) are more succeptible to be chosen as best reagent to stabilizing soil.
\end{abstract}

Keyword: Colloidal stability; Electroosmotic; Isoelectric point; Zeta potential 